2. To: (Receiving Organization)

Distribution

5. Proj./Prog./Dept./Div.:

Spent Nuclear Fuel Project

8. Originator Remarks:

N/A
3. From: (Originating Organization)

SNF Project

6. Design Authority/ Design Agent/Cog. Engr:

C. Van Katwijk
4. Related EDT No::

N/A

7. Purchase Order No.:

N/A

9. Equip./Component No::

N/A

10. System/Bldg./Facility:

Spent Nuclear Facility

11. Receiver Remarks: 11A. Design Baseline Document? [] Yes [X] No

12. Major Assm. Dwg. No.:
N/A

13. Permit/Permit Application No.:

N/A

14. Required Response Date:

$\mathrm{N} / \mathrm{A}$

\begin{tabular}{|c|c|c|c|c|c|c|c|c|}
\hline 15. & \multicolumn{4}{|c|}{ DATA TRANSMITTED } & (F) & (G) & (H) & (I) \\
\hline $\begin{array}{l}(A) \\
\text { ltem } \\
\text { No. }\end{array}$ & (B) Document/Drawing No. & $\begin{array}{l}\text { (C) } \\
\text { Sheet } \\
\text { No. }\end{array}$ & $\begin{array}{l}\text { (D) } \\
\text { Rev. } \\
\text { No. }\end{array}$ & $\begin{array}{l}\text { (E) Title or Description of Data } \\
\text { Transmitted }\end{array}$ & $\begin{array}{c}\text { Approval } \\
\text { Desig- } \\
\text { nator }\end{array}$ & $\begin{array}{l}\text { Reason } \\
\text { for } \\
\text { Trans- } \\
\text { mittal }\end{array}$ & $\begin{array}{l}\text { Origi- } \\
\text { nator } \\
\text { Dispo- } \\
\text { sition }\end{array}$ & $\begin{array}{l}\text { Receiv- } \\
\text { er } \\
\text { Dispo- } \\
\text { sition }\end{array}$ \\
\hline 1 & SNF-3892 & & 0 & $\begin{array}{l}\text { MKS Baratron MCO Absolute Pressure } \\
\text { Transmitter }\end{array}$ & $Q$ & 2 & 1 & N/A \\
\hline & & & & & & & & \\
\hline & & & & & & & & \\
\hline & & & & & & & & \\
\hline & & & & & & & & \\
\hline
\end{tabular}

KEY

\begin{tabular}{|l|ll|lc|}
\hline \multicolumn{1}{|c|}{ Approval Designator (F) } & \multicolumn{1}{|c|}{ Reason for Transmittal (G) } & \multicolumn{1}{c}{ Disposition (H) \& (l) } \\
\hline E, S, Q, D or N/A & 1. Approval & 4. Review & 1. Approved & 4. Reviewed no/comment \\
(see WHC-CM-3-5, & 2. Release & 5. Post-Review & 2. Approved w/comment & 5. Reviewed w/comment \\
Sec.12.7) & 3. Information & 6. Dist. (Recejpt Acknow. Required) & 3. Disapproved w/comment & 6. Receipt acknowledged \\
\hline
\end{tabular}
17. SIGNATURE/DISTRIBUTION

(See Approval Designator for required signatures)

\begin{tabular}{|c|c|c|c|c|c|}
\hline $\begin{array}{l}\text { (G) } \\
\text { Rea- } \\
\text { son }\end{array}$ & $\begin{array}{l}\text { (H) } \\
\text { Disp. }\end{array}$ & $\begin{array}{llll}\text { (J) Name } & \text { (K) Sigrature } & \text { (L) Date } & \text { (M) MSIN }\end{array}$ & $\begin{array}{l}\text { (G) } \\
\text { Rea- } \\
\text { Son }\end{array}$ & $\begin{array}{l}\text { (H) } \\
\text { Disp. }\end{array}$ & $\begin{array}{llll}\text { (J) Name } & \text { (K) Signature } & \text { (L) Date } & \text { (M) MSIN }\end{array}$ \\
\hline 2 & $t$ & Designated Engineer C. Van Katw & & & \\
\hline 2 & 1 & Design Authority R. Whitehurst $/ 2 h \sim \sim 2 / 39$ & & & \\
\hline 2 & 1 & QA T.D. Hays Wo klame $3 / 30 / 49$ & & & \\
\hline & & & & & \\
\hline & & & & & \\
\hline & & & & & \\
\hline & & & & & \\
\hline
\end{tabular}

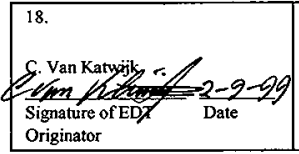

19.

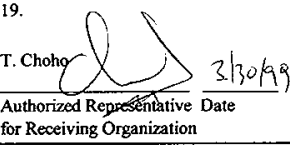

20.

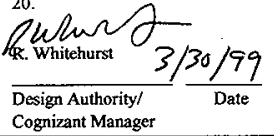

21. DOE APPROVAL (if required) Ctrl. No.

D] Approved

[] Approved w/comments

D Disapproved w/comments 


\section{MKS Baratron MCO Absolute Pressure Transmitter}

Carl Van Katwijk

Numatec Hanford Co, Richland, WA 99352

U.S. Department of Energy Contract DE-AC06-96RL13200

EDT/ECN: 626265

Org Code: $2 \mathrm{G} 300$

B\&R Code: 39EW40400
UC: 620

Charge Code: 105559/A000

Total Pages: 13

Key Words: Absolute Pressure Transmitter - MCO

Abstract: MKS Baratron MCO Absolute Pressure Transmitter

CGI-SNF-D-13-P4-019

TRADEMARK DISCLAIMER. Reference herein to any specific commercial product, process, or service by trade name, trademark, manufacturer, or otherwise, does not necessarily constinte or imply its endorsement, recommendation, or favoring by the United States Government or any agency thereof or its contractors or subcontractors.

Printed in the United States of America. To obtain copies of this document, contact: Document Control Services, P.O. Box 950, Mailstop H6-08, Richland WA 99352, Phone (509) 372-2420; Fax (509) 376-4989.

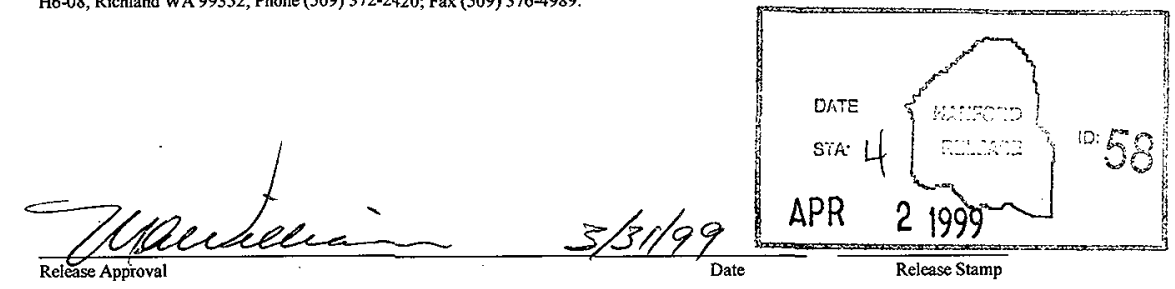

\section{Approved for Public Release}


Commercial Grade Item Upgrade Dedication Form

ECN No. NA

CGI No. CGI-SNF-D-13-P4-019

Page 1 of 12

Title: MKS BARATRON MCO ABSOLUTE PRESSURE TRANSMITTER

6ector

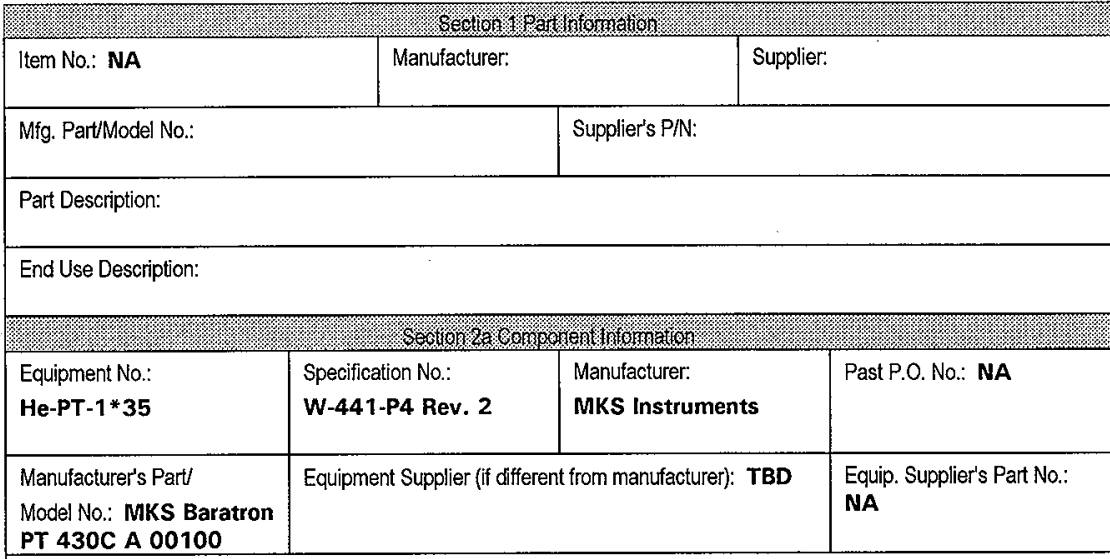

Component Description: MKS Baratron high resolution absolute pressure transmitter designed for MCO vacuum processes (100 TORR) using capacitance manometer. Measure and transmit MCO pressure. Electronic output signal is NON-SAFETY (GS).

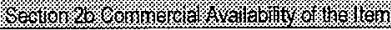

1. Is the ltem available from a catalogue from a qualified NQA1 supplier interface Engineer or BTR)?

I ] YES (go to \#2 below)

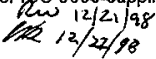

[X] NO (go to procedure step 5.3.2, proceed to dedicate ltem)

2. List of Candidate qualified suppliers or 300

company name \& type

contact namerk $12 / 23 / 98$

phone

NA

3. Recommended Procurement Strategy(coordinate with project CGI interface Engineer or BTR):

NA

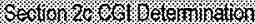

1. Question \#1: Is the ltem subject to design or specification requirements that are unique to nuclear facilities or activities?

I I YES (the ltem is not commercial grade)

[X] NO (continue)

2. Question \#2: is the Item used in applications other than nuclear facilities or activities?

l ] NO (the item is not commercial grade)

[X] YES (continue) 
Commercial Grade Item Upgrade Dedication Form

3. Question \#3: Is the Ifem ordered from manufacturer/supplier on the basis or specifications set forth in the manufacturers catalog?

1 ] NO (the Item is not commercial grade)

[X] YES (continue)

[X] All three criteria have been satisfied. The Item meets the definition of commercial grade.

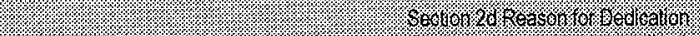

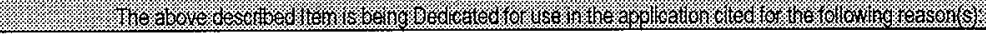

[ $\mathbf{X}$ ] Item is being purchased from a non ESL manufacturer supplier as commercial grade to be used in a Safety Class application.

[ ] Item is being purchased from a non ESL manufacturer supplier as commercial grade to be used in a Safety Significant application.

[ ] Item was purchased from a non ESL manufacturer supplier as commercial grade to be used in a Safety Class application.

1 1 Item was purchased from a non ESL manufacturer supplier as commercial grade to be used in a Safety Significant application.

l 1 Other ('like-for-like', similar, substitution, replacement evaluation)

A. Part/Component Safety Function:

1. Pressure Boundary

2. Maintain Pressure Boundary After Seismic Event

3.

B. Part/Component Functional Mode:

Safety Function \#1:

[ ] Active - Mechanical or Electrical change of state is required to occur for the component to perform its safeity function

[X] Passive - Change of state is not required for the component to perform its safety function Safety Function \#2:

1 ] Active - Mechanical or Electrical change of state is required to occur for the component to perform its safety function.

[X] Passive - Change of state is not reguired for the component to perform its safely function Safety Function \#3:

I ] Active - Mechanical or Electrical change of state is required to occur for the component to perform its safety function.

1 Passive - Change of state is not required for the component to perform its safety function

C. Host Component Safety Function (if applicable):

1. NA

2.

3. 
D. Failure Mode(s) and the effects on component or system safety function (see Worksheet 1):

1. PT process connection break/PT body break - inleakage of air.

2. Inaccurate pressure signal due to damage from pressure outside instrument indicator range.

3.

4.

5.

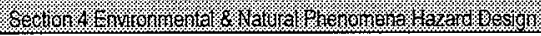

Environmental Qualification Required:

Yes [ ]

If yes: Environmental Qualification Requirements

No [X]

Limiting Environmental Conditions:

Required Safety Functions:

Environmental Condition B

Qualification Period:

Natural Phenomena Hazard (NPH) Design Required:

If yes: NPH Design Requirements

Performance Category: PC-3

Yes [X]

NPH Design Req'ts.: Seismic Condition B

No [ ]

Required Safety Functions: Pressure Boundary

HNF-PRO-97, Rev. 0

Integrity

W-441-P4, Rev. 2

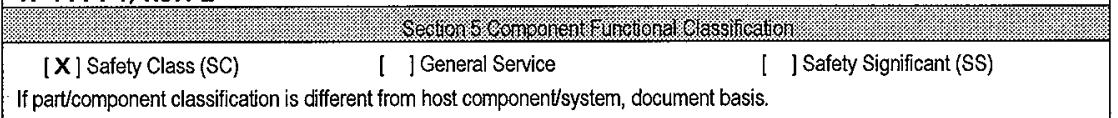

If part/component classification is different from host component/system, document basis.

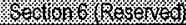

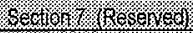

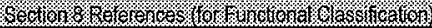

National Codes/Standards:

IEEE 344, ISA-S5.1, S5.4, \$18.1, $\$ 20$
Safety Analysis Report (SAR):

HNF-SD-SNF-SAR-002,

Rev. 4A
Drawings: H-1-82161, Rev. 2

HNF-SD-SNF-SEL-002, Rev. 4

Vendor Manual/Manufacturer/Supplier Information: MKS Instruments Baratron Absolute Pressure Transmitters 400 Series

Other: 
Commercial Grade Item Upgrade Dedication Form

ECN No. NA

CGINo. CGI-SNF-D-13-P4-019

Title: MKS BARATRON MCO ABSOLUTE PRESSURE TRANSMITTER

\begin{tabular}{|c|c|c|c|c|c|}
\hline & \multicolumn{2}{|l|}{ 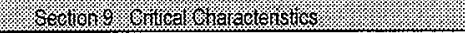 } & & & \\
\hline $\begin{array}{l}\text { Critical Characteristics Verification } \\
\text { Document: Vendor Specifications; } \\
\text { HNF-SD-SNF-SEL-002 Rev. } 4\end{array}$ & \multicolumn{2}{|l|}{ Acceptance Criteria/Tolerances } & $\begin{array}{l}\text { Acceptance } \\
\text { Method }\end{array}$ & ID & Function \\
\hline \multicolumn{6}{|c|}{ 1. Item Identification Critical Characteristios (necessary for reasonable assurance that the Item delivered is the Item specified) } \\
\hline Nameplate Data & \multicolumn{2}{|c|}{ Per Vendor Manual } & 1, IN & $\mathbf{x}$ & \\
\hline Model/Part Number. & \multicolumn{2}{|l|}{$430 \mathrm{CA} A 0100$} & $1, \mathrm{IN}$ & $\mathrm{x}$ & \\
\hline Housing & \multicolumn{2}{|l|}{ NEMA 4} & $1, \mathrm{IN}$ & $\mathrm{x}$ & \\
\hline Process Connection & \multicolumn{2}{|l|}{$1 / 4-18 \mathrm{NPT}$} & 1, IN & $\mathbf{x}$ & \\
\hline \multicolumn{6}{|c|}{ 2. Physical Critical Characteristics (for reasonable assurance that the Item delivered is the Item specified) } \\
\hline Material, Body & \multicolumn{2}{|c|}{ Cast Aluminum } & $1, \mathrm{~T}$ & $\mathrm{x}$ & \\
\hline Material, Process Connection & \multicolumn{2}{|l|}{ Stainless Steel } & 1, T & $\mathrm{X}$ & \\
\hline \multicolumn{6}{|c|}{ 3. Performance Critical Characteristics (for reasonable assurance that the ltem will perform its intended safety function(s)) } \\
\hline Pressure Boundary & \multicolumn{2}{|c|}{$\begin{array}{l}\text { Pressure Test at Pressure of } 165 \text { Psig (No } \\
\text { Leakage) Notes } 3 \text { and } 4\end{array}$} & $1, T$ & & $x$ \\
\hline Repeatability & \multicolumn{2}{|c|}{ NA } & & & \\
\hline $\begin{array}{l}\text { Input/Output Voltage/ } \\
\text { Operating Range/ } \\
\text { Accuracy }\end{array}$ & \multicolumn{2}{|l|}{ NA } & & & \\
\hline Insulation Resistance & \multicolumn{2}{|l|}{ NA } & & & \\
\hline Environmental & \multicolumn{2}{|l|}{ Note 1} & & & \\
\hline Seismic Condition B & Notes 2 and 4 & & $1, T$ & & $\mathbf{x}$ \\
\hline \multicolumn{2}{|c|}{$\begin{array}{l}\text { 2. Maintain pressure boundary after Seismic event. W-441-P4, } \\
\text { Rev. 2, Appendix } \mathrm{L} \text {, page L-12, provides a seismic testing plan } \\
\text { for these components at a (TBD) seismic spectra. } \\
\text { "Confinement" leakage acceptance criteria is }<10^{-4} \text { scc/sec. } \\
\text { 3. Pressure test at } 110 \% \text { of design accident condition pressure of } \\
150 \text { psig (Destructive Test). Vendor sheet states overpressure } \\
\text { limit of } 35 \text { psig, consequentiy this test is considered to be a } \\
\text { destructive test. } \\
\text { 4. Testing (Seismic and pressure boundary) is being performed for } \\
\text { PT- } 1 * 08 \text { (CGI-SNF-D-07-P4-010). Both instruments are Baratron } \\
\text { Series } 400 \text { and have identical pressure boundaries. Destructive } \\
\text { testing of PT- } 1 * 08 \text { will provide verification of the critical } \\
\text { characteristics for this component. }\end{array}$} & \multicolumn{4}{|c|}{$\begin{array}{l}\text { Acceptance Method: } \\
\text { 1. Special Test and Inspection } \\
1, \text { IN for Inspection } \\
1, \mathrm{~T} \text { for Test } \\
\text { 2. Commercial Grade Survey } \\
\text { 3. Source Verification } \\
\text { 4. Vendor/ltem History }\end{array}$} \\
\hline
\end{tabular}




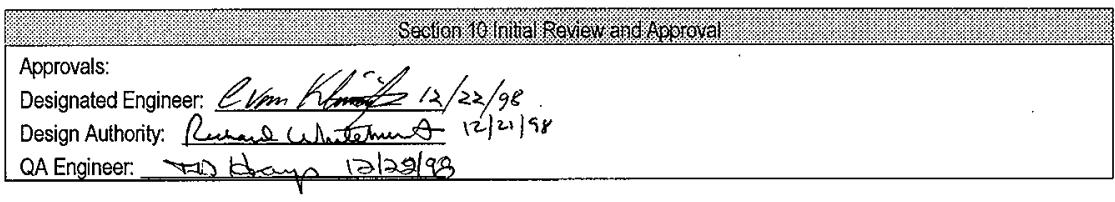




Commercial Grade Item Upgrade Dedication Form
\begin{tabular}{|l|lr|}
\hline ECN No. NA CGI No. CGI-SNF-D-13-P4-019 & Rev. No. 0 \\
Tille: MKS BARATRON MCO ABSOLUTE PRESSURE TRANSMTTTER & & SNF-3892 12 \\
\hline
\end{tabular}

\begin{tabular}{|c|c|c|}
\hline \multicolumn{3}{|c|}{$\begin{array}{c}\text { WORKSHEET } 1 \\
\text { DETERMINATION OF FAILURE MECHANISMSIMODES }\end{array}$} \\
\hline (3) & \multirow{2}{*}{$\frac{x_{2}}{\text { Definition }}$} & \multirow{2}{*}{$\begin{array}{l}\text { Applicable to Component } \\
\text { under Evaluation }\end{array}$} \\
\hline $\begin{array}{l}\text { Typical Failure } \\
\text { Mechanisms }\end{array}$ & & \\
\hline Fracture & $\begin{array}{l}\text { Separation of a solid accompanied by little or no } \\
\text { macroscopic plastic deformation. }\end{array}$ & $\begin{array}{l}\text { Yes [ ] No [X]; If Yes, indicate failure } \\
\text { Mode }\end{array}$ \\
\hline Corrosion & $\begin{array}{l}\text { The gradual deterioration of a material due to } \\
\text { chemical or electrochemical reactions, such as } \\
\text { oxidation, between the material and its environment. }\end{array}$ & $\begin{array}{l}\text { Yes [ ] No [X]; if Yes, indicate failure } \\
\text { Mode }\end{array}$ \\
\hline Erosion & $\begin{array}{l}\text { Destruction of materials by the abrasive action of } \\
\text { moving fluids, usually accelerated by the presence } \\
\text { of solid particles caried with the fluid. }\end{array}$ & $\begin{array}{l}\text { Yes [ ] No [X]; if Yes, indicate failure } \\
\text { Mode }\end{array}$ \\
\hline Open Circuit & $\begin{array}{l}\text { An electrical circuit that is unintentionally broken so } \\
\text { that there is no complete path for current flow. }\end{array}$ & $\begin{array}{l}\text { Yes [ ] No [X]; If Yes, indicate failure } \\
\text { Mode }\end{array}$ \\
\hline Short Circuit & $\begin{array}{l}\text { An abnormal connection by which an electrical } \\
\text { current is connected to ground, or to some }\end{array}$ & $\begin{array}{l}\text { Yes [ ] No [X]; If Yes, indicate failure } \\
\text { Mode }\end{array}$ \\
\hline Blockage & $\begin{array}{l}\text { conducting body, resulting in excessive current flow. } \\
\text { Clogging of a fittering medium resulting in the } \\
\text { inability to perform its purification function or } \\
\text { blockage of flow. }\end{array}$ & $\begin{array}{l}\text { Yes [ ] No [X]; if Yes, indicate failure } \\
\text { Mode }\end{array}$ \\
\hline Seizure & $\begin{array}{l}\text { Binding of a normally moving item through excessive } \\
\text { pressure, temperature, friction, jamming. }\end{array}$ & $\begin{array}{l}\text { Yes [ ] No [ } \mathrm{X} \text { ]; If Yes, indicate failure } \\
\text { Mode }\end{array}$ \\
\hline $\begin{array}{l}\text { Unacceptable } \\
\text { Vibration }\end{array}$ & $\begin{array}{l}\text { Mechanical oscillations produced are beyond the } \\
\text { defined permissible limits due to unbalancing, poor } \\
\text { support, or rotation at critical speeds. }\end{array}$ & $\begin{array}{l}\text { Yes [ ] No [X [; If Yes, indicate failure } \\
\text { Mode }\end{array}$ \\
\hline Loss of Properties & $\begin{array}{l}\text { A loss of mechanical and physical properties of a } \\
\text { material due to exposure to high temperatures, } \\
\text { radiation exposure. }\end{array}$ & $\begin{array}{l}\text { Yes [ ] No [X]; If Yes, indicate failure } \\
\text { Mode }\end{array}$ \\
\hline Excess Strain & $\begin{array}{l}\text { Under the action of excessive extemal forces the } \\
\text { material of the part has been deformed or distorted. }\end{array}$ & $\begin{array}{l}\text { Yes [ I No [X]; if Yes, indicate failure } \\
\text { Mode }\end{array}$ \\
\hline Mechanical Creep & $\begin{array}{l}\text { From prolonged exposure to high temperature and } \\
\text { stress, the object will show a slow change in its }\end{array}$ & $\begin{array}{l}\text { Yes [ ] No [X]; If Yes, indicate failure } \\
\text { Mode }\end{array}$ \\
\hline Ductile Fracture & $\begin{array}{l}\text { characteristics. } \\
\text { Fracture characterized by tearing of metal } \\
\text { accompanied by appreciable gross plastic } \\
\text { deformation. }\end{array}$ & $\begin{array}{l}\text { Yes [ I No [X]; If Yes, indicate failure } \\
\text { Mode }\end{array}$ \\
\hline \multicolumn{3}{|c|}{ 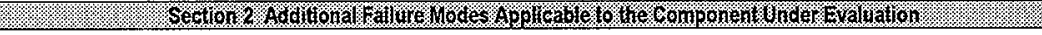 } \\
\hline \multicolumn{3}{|c|}{ 1. Process Connection Break } \\
\hline \multicolumn{3}{|c|}{ 2. Transmitter Body Break } \\
\hline \multicolumn{3}{|c|}{ 3. Diaphragm Assembly Loss } \\
\hline \multicolumn{3}{|c|}{ 4. Deformation due to excessive pressure. } \\
\hline 5. & & \\
\hline
\end{tabular}


Commercial Grade Item Upgrade Dedication Form

\section{CHECKLIST 1}

ACCEPTANCE METHOD 1

SPECIAL TEST/INSPECTION VERIFICATION

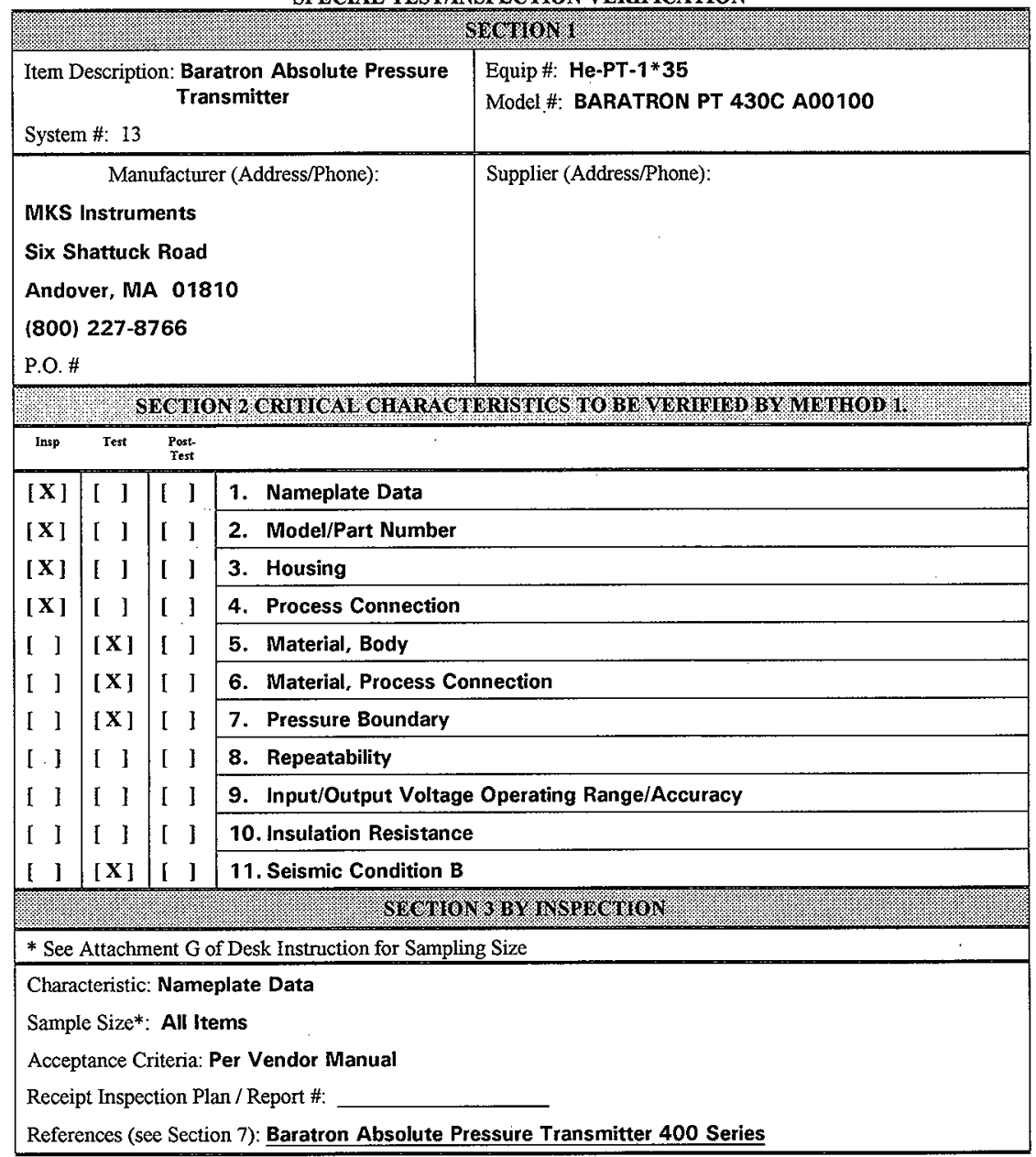




\section{Characteristic: Model/Part Number}

Sample Size*: All Items

Acceptance Criteria: $430 \mathrm{C}$ A00100

Receipt Inspection Plan / Report \#:

References (see Section 7):

Characteristic: Housing

Sample Size*: All Items

Acceptance Criteria: NEMA 4

Receipt Inspection Plan / Report \#:

References (see Section 7):

Characteristic: Process Connection

Sample Size*: All Items

Acceptance Criteria: $1 / 4$ - 18 NPT

Receipt Inspection Plan / Report \#:

References (see Section 7):

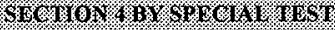

* See Attachment G of Desk Instruction for Sampling Size

\begin{tabular}{|c|c|}
\hline $\begin{array}{l}\text { Test To Be Performed by: } \\
\text { [ ] Purchaser } \\
\text { I ] Supplier/Manufacturer** } \\
\text { [ ] Other }\end{array}$ & $\begin{array}{l}\text { Number of Items to be Tested: } \\
\text { Test/Inspection Location: }\end{array}$ \\
\hline
\end{tabular}

Characteristic for Test: Material, Body

Acceptance Criteria: Cast Aluminum

Sample Size*: Normal Sampling Size

Actual Test Value:

Test Plan and Report \#: References (see Section 7):

Characteristic for Test: Material, Process Connection

Acceptance Criteria: Stainless Steel

Sample Size*: Normal Sampling Size

Actual Test Value:

Test Plan and Report \#: References (see Section 7): 
Title: MKS BARATRON MCO ABSOLUTE PRESSURE TRANSMITTER

Characteristic for Test: Pressure Boundary

Acceptance Criteria: Pressure Test at Pressure of 165 Psig (No Leakage)

Sample Size*: Destructively Test Only One Item. Pressure boundary testing is being performed for PT-1*08 (CGI-SNF-D-07-P4-010). Both instruments are Baratron Series 400 and have identical pressure boundaries. Destructive testing of PT-1*08 will provide verification of the critical characteristics for this component.

Actual Test Value:

Test Plan and Report \#: References (see Section 7):

Characteristic for Test: Seismic Condition B

Acceptance Criteria: Maintain Pressure Boundary After Seismic Event. W-441-P4, Rev. 2, Appendix $L$, page L-12, provides a seismic testing plan for these components at a (TBD) seismic spectra. "Confinement" leakage acceptance criteria is $<10-4 \mathrm{scc} / \mathrm{sec}$.

Sample Size*: Seismic Testing is being performed for PT-1*08 (CGI-SNF-D-07-P4-010). Both instruments are Baratron Series $\mathbf{4 0 0}$ and have identical pressure boundaries. Destructive testing of of PT-1*08 will provide verification of the critical characteristics for this component.

Actual Test Value:

Test Plan and Report \#: References (see Section 7):

Characteristic for Test:

Acceptance Criteria:

Sample Size*:

Actual Test Value:

Test Plan and Report \#: References (see Section 7):

Characteristic:

Acceptance Criteria:

Sample Size*:

Actual Test Value:

Test Plan and Report \#: References (see Section 7):

**If Supplier/Manufacturer or Other, Refer to CGI Checklist-2 for Support Information 


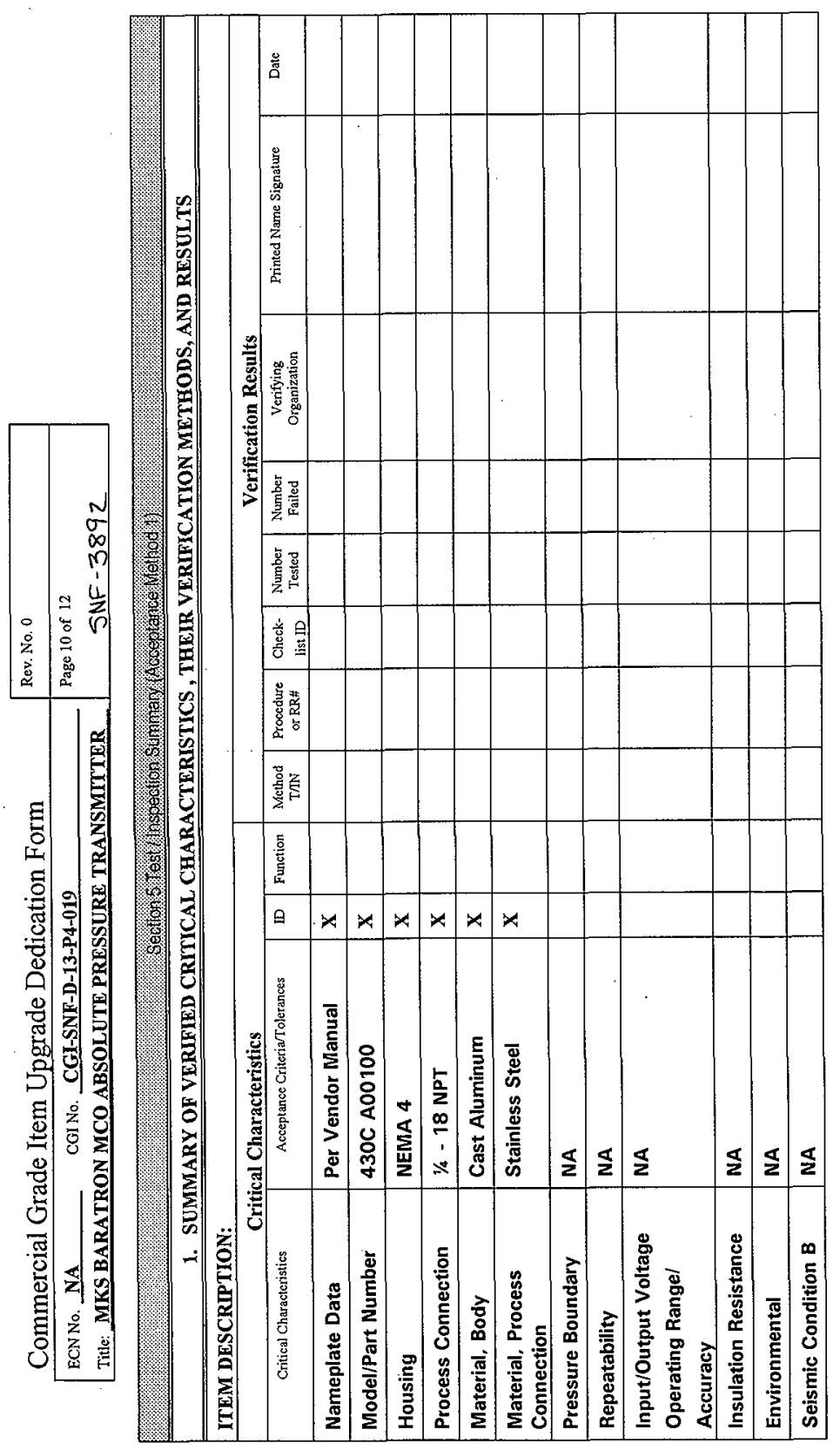

$\stackrel{\infty}{\Omega}$
ㄱ
ㄱ 


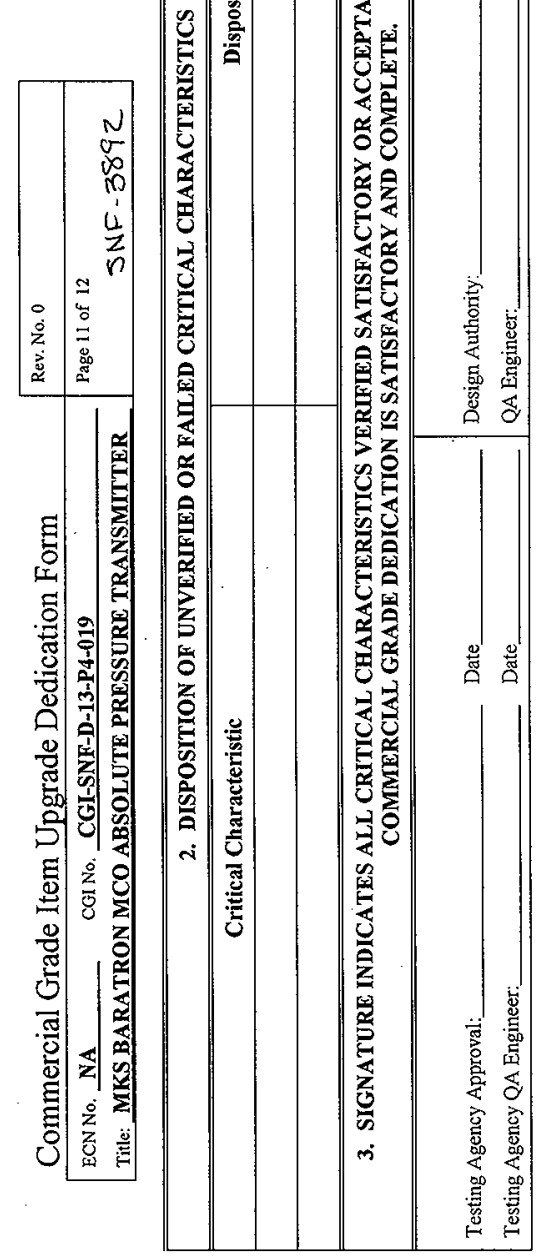

$\stackrel{\infty}{\stackrel{2}{\pi}}$ 
Commercial Grade Item Upgrade Dedication Form

ECN No. NA CGI No. CGI-SNF-D-13-P4-019

Title: MKS BARATRON MCO ABSOLUTE PRESSURE TRANSMITTER

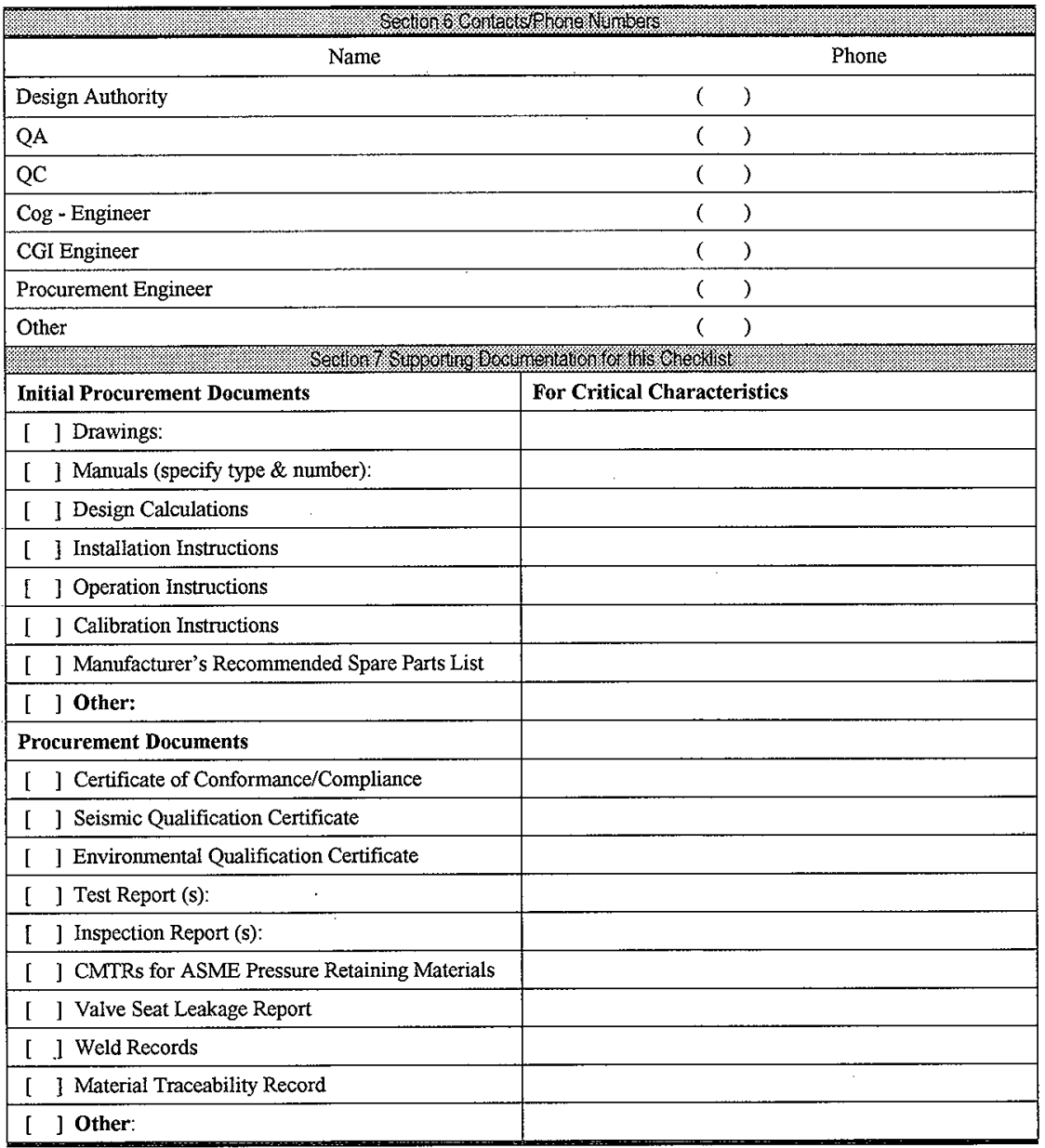

